\title{
CORRIGENDUM
}

\section{A field method for evaluating frost injury to lucerne}

\author{
D. G. STOUT, J. HALL, BARBARA BROOKE AND T. MOORE \\ J. agric. Sci., Camb. (1988), 111, 171-177
}

The Editors regret the omission from the paper of the explanation for Plate 1, facing p. 172, as follows:

\section{EXPLANATION OF PLATE}

Example of visual lesions used to evaluate winter injury: (a) viable buds (arrow) are white, turgid, and may be pink tipped; (b) injured buds (arrows) are dry, discoloured, limp, or shrivelled and dry; (c) bark is more easily peeled from injured roots; $(d)$ injured roots are soft and easily squeezed; also note white fungal mycelium; $(e)$ non-injured (left) root interiors are white, whereas injured (right) root interiors may be discoloured; note that discoloration from disease (left arrow) must be separated from that caused by winter injury (right arrow). The extent of leaf development at the time of sampling is demonstrated in $(e)$. 